\title{
Obituaries
}

\section{JAMES MARSHALL (1913-79)}

After 31 years in South Africa, James Marshall collapsed and died on 12 November 1979 aged 66 years, for 15 of which he had been the distinguished head of the department of dermatology at the Medical School of the University of Stellenbosch. Earlier in 1948, when he started a private practice in Johannesburg,

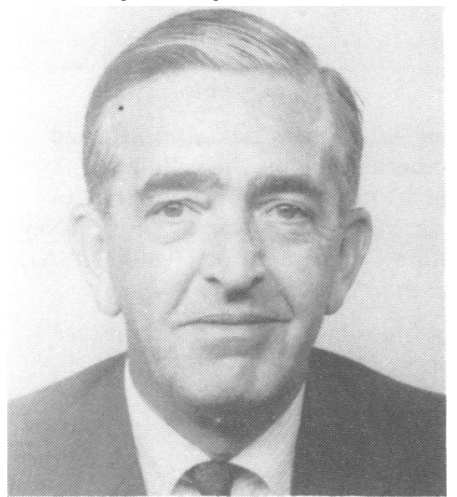

he was given charge of the department of skin diseases at the University of Pretoria and, with a natural linguistic bent, was soon able to lecture in Afrikaans, which he continued to do after moving to the Cape in 1956. Apart from his longstanding international reputation, to quote a

\section{SAJJAD HAMEED QURESHI (1937-80)}

Dr "Sam" Qureshi, who died recently under tragic circumstances at the age of 42 , was undoubtedly the best registrar I have been associated with in my clinics, and he became a firm friend. His medical career was a distinguished one and among his many earlier achievements was the award of "best graduate of the year" in 1958 at the King Edward Medical College (Punjab).

After a series of varied junior posts in hospitals in this country he became neurological registrar at the Churchill Hospital, Oxford, and was in virtual charge of the tubercular meningitis unit where he could exercise his undoubted medical skill to the full. After a spell of four years as registrar at the STD clinic at the Central Middlesex Hospital he obtained the post of senior registrar at the STD clinic, St Thomas's Hospital. He was clearly ready to become a prominent consultant in his field when his illness forced him to become a colleague, "The credit for the high standard of dermatology in South Africa goes to him in no small measure."

It has also been written that Marshall arrived in dermatology "through the doorway of venereal diseases" and his passage will be remembered with much affection by older venereologists, especially those associated with him in London during the war years.

Born in Glasgow in 1913, after qualifying with distinction at the London Hospital at the young age of 21 , he later served as resident medical officer at the London Lock Hospital. Having studied for a while in Paris (perfecting his already able French tongue) he acquired a life-long addiction for that country's medical and culinary traditions. (His visits to Europe later in life were centred more on France than Britain.)

Come the war, he joined the Army to be posted as venereologist to the Military Isolation Hospital, Harrow Road, London, previously the female section of the Lock Hospital, which catered only for skin and venereal diseases. Here, as major, he wrote his textbook on The Venereal Diseases, which was published in 1944. Subsequently (as lieutenant colonel) he succeeded Brigadier $T E$ Osmond as adviser in venereology to the War Office, which post he held until the end of 1945 , by which time

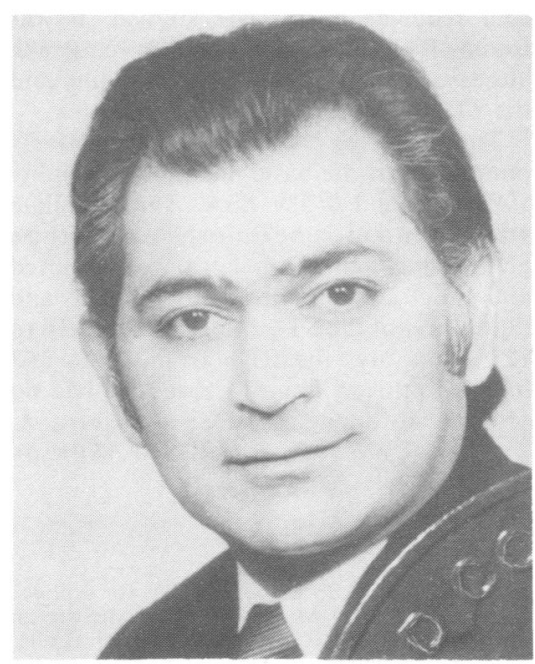
he had initiated a private practice based in $\frac{\text { 을 }}{\text { Jermyn Street, London. }}$
$\frac{\text {. }}{5}$

Back in civilian life he was soon $\bar{Q}$ appointed director of the venereal disease clinic at the Royal Northern Hospital and then consulting dermatologist to the $\vec{\circ}$ Central Middlesex County Hospital. Almost immediately his companion book, $\vec{\omega}$ The Skin Diseases, in which he promulgated his belief along with the? French school of dermatologists "that'g dermatology and syphilology areicr inseparable," was published in 1948. By the w time the second edition of The Venerealc Diseases appeared also in the sameo year-the National Health Service was thenbeing introduced in Britain-his decision to emigrate to South Africa had already beeno taken.

His down-to-earth approach to lifeabundantly laced with wit and humour, tinged with cynicism, but tempered with $\mathrm{a}_{\infty}$ warmth and generosity-gave him a. magnetic quality which endeared him to his friends. He certainly showed the writer wider vistas, particularly the full enjoyment which can be obtained from venereology not least from combining routine work with research and writing.

He was happily married to Eileen Mary Platt for 40 years, to whom the deepest 3 sympathies are extended.-RRW.

patient at that hospital, where he $\operatorname{died}_{\infty}$ showing exemplary courage during this? tragic period.

The first and lasting impressions formed were a sense of calm, compassion, 8 competence, and a sense of humour. This made him deservedly popular witho colleagues and patients alike. He was also? exceptional in many fields, being chosen for $\frac{7}{0}$ the Olympic hockey team to represent his country, but he declined in order to devote $N$ his time and energy to medicine, which remained his lasting love. He was very well read, outstandingly musical, and anc excellent organiser.

In have no doubt that our profession has lost a splendid consultant-to-be and the best way I can sum up his many good qualititieses is by saying that he was a gentleman in the literal sense. He will be missed by his many friends and faithful patients and they will extend their genuine sympathy to his wife.-GC 